A Neo-Downsian Model of the Alternative Vote as a Mechanism for Mitigating Ethnic Conflict in Plural Societies

Author(s): Jon Fraenkel and Bernard Grofman

Source: Public Choice, Vol. 121, No. 3/4 (Oct., 2004), pp. 487-506

Published by: Springer

Stable URL: http://www.jstor.org/stable/30026552

Accessed: $12 / 04 / 2010$ 20:02

Your use of the JSTOR archive indicates your acceptance of JSTOR's Terms and Conditions of Use, available at http://www.jstor.org/page/info/about/policies/terms.jsp. JSTOR's Terms and Conditions of Use provides, in part, that unless you have obtained prior permission, you may not download an entire issue of a journal or multiple copies of articles, and you may use content in the JSTOR archive only for your personal, non-commercial use.

Please contact the publisher regarding any further use of this work. Publisher contact information may be obtained at http://www.jstor.org/action/showPublisher?publisherCode=springer.

Each copy of any part of a JSTOR transmission must contain the same copyright notice that appears on the screen or printed page of such transmission.

JSTOR is a not-for-profit service that helps scholars, researchers, and students discover, use, and build upon a wide range of content in a trusted digital archive. We use information technology and tools to increase productivity and facilitate new forms of scholarship. For more information about JSTOR, please contact support@jstor.org. 


\title{
A neo-Downsian model of the alternative vote as a mechanism for mitigating ethnic conflict in plural societies*
}

\author{
JON FRAENKEL ${ }^{1} \&$ BERNARD GROFMAN ${ }^{2}$ \\ ${ }^{1}$ Economics Department, School of Social and Economic Development, University of the \\ South Pacific,Suva, Fiji; e-mail: fraenkel_J@USP.AC.FJ; ${ }^{2}$ Department of Political Science \\ and Institute for Mathematical Behavioral Science, University of California, CA 92697-5100, \\ Irvine,U.S.A.; e-mail: bgrofman@uci.edu
}

Accepted 9 September 2003

\begin{abstract}
Among those advocating the use of particular electoral mechanisms to reduce the prospects for conflict and strengthen democracy in societies that are deeply divided in ethnic or religious terms, there are two main approaches, one associated with Arend Lijphart, one with Donald Horowitz. Lijphart advocates using electoral rules such as list $P R$ that strengthen the power of ethnically or religiously defined political elites in the context of implementing powersharing mechanisms at the elite level that institutionalize norms such as proportional allocation and mutual veto across ethnies. Horowitz advocates using a preferential voting method, the alternative vote $(A V)$, within constituencies that are multi-ethnic in character, to allow for voting across ethnic lines and to increase the likelihood of electing candidates whose perceived obligations are wider than their own ethnic group and/or to foster the creation of coalitions that are multi-ethnic in character. The main focus of this essay is the reformulation of Horowitz's approach in terms of ideas adapted from the neo-Downsian literature on median voter models. We illustrate Horowitz's approach with illustrations inspired by the predominantly biracial political competition in Fiji between native Fijians and those of Indian descent.
\end{abstract}

\section{Introduction}

A fundamental challenge faced by many countries is the accommodation of ethnic and religious diversity. In the worst case, we may have civil wars between competing ethnies ${ }^{1}$ that are fought with genocidal fury, as in Rwanda. The search for methods to mitigate or resolve conflicts in plural societies $^{2}$ has been a major concern of both scholars and politicians, and there is a vast literature on this topic (see e.g., Diamond and Plattner, 1994). ${ }^{3}$ The solutions proposed to ethnic conflicts in plural societies can, roughly

* The second-named author is indebted to helpful conversations over the years with Arend Lijphart and Andrew Reynolds, and to Clover Behrend for bibliographic assistance. The participation of the second author in this research was supported by National Science Foundation Grant \# SBR 446740-21167, Program in Methodology, Measurement, and Statistics (to Bernard Grofman and Anthony Marley). The views expressed in this paper are solely those of the authors. 
speaking, be arrayed on a continuum anchored at one end by those who see at least the temporary need to "build restraining walls" between ethnic communities in conflict, e.g., through ethnically-linked territorial federalism, and related mechanisms such as monoethnic electoral constituencies or ethnic electoral rolls and communally-based legal and educational systems; ${ }^{4}$ and those who see the solution in terms of integrating communities in conflict by creating a strong sense of overriding national identity and a legal system with strong individual civil rights and individual civil liberties, with the aim of minimizing the importance of ethnicity for political life and for social and economic opportunity. In particular, advocates of this latter approach usually believe it important to avoid allocative mechanisms that are ethnically based. While it is certainly possible for scholars to take a "mix and match" point of view, more often, ${ }^{5}$ particular scholars tend to fall toward one or the other end of the continuum we have identified.

This general debate about appropriate institutional design for plural societies plays itself out in terms of arguments about choice of electoral system. The latter debate has largely been waged between those who advocate electoral rules such as list proportional representation $(P R)$ that strengthen the power of (ethnically-defined) political elites, with the aim of implementing power-sharing mechanisms at the elite level that institutionalize norms such as proportional allocation and mutual veto across ethnies; and those who advocate electoral rules such as the alternative vote $(A V)$ or its multi-seat version, the single transferable vote $(S T V),{ }^{6}$ and the creation of constituencies that are multi-ethnic in character, with the aim of fostering voting across ethnic lines (vote pooling) and the election of candidates with perceived obligations wider than their own ethnic group and/or the creation of parties that are multi-ethnic in character.

The two key academic protagonists in the debate over the appropriate electoral system to use in plural societies are Arend Lijphart, in his work on power sharing and consociationalism (e.g., Lijphart, 1977, 1991b, 1996, 1997), and Donald Horowitz, in his work on constitutional design and ethnic accommodation (e.g., Horowitz, 1991a, b, c; 1993). The former has advocated list PR, the latter methods such as AV. ${ }^{7}$ Their two approaches to electoral system choice in plural societies are widely viewed as being in direct opposition to one another, both by academics studying ethnic conflict (see e.g., Sisk, 1996) and by politicians in plural societies, themselves. ${ }^{8}$

Our focus in this paper is on Horowitz's approach to the use of the alternative vote as a tool for mitigating ethnic conflict. In particular, we formalize Horowitz's claims about the implications of AV for ethnic conflict in terms of ideas from the neo-Downsian party competition literature on median voter models, inspired by Downs (1957), and the Social Choice 
literature on single-peaked preferences. ${ }^{9}$ We show that implicitly Horowitz is positing the application of $\mathrm{AV}$ to biracial/bi-ethnic situations where politics can be thought of as being arrayed primarily along a unidimensional continuum where voters have (single-peaked) preferences with respect to a continuum of ethnic allegiance. In such situations we will consider theoretical issues specifying the circumstances under which $\mathrm{AV}$ might serve as a tool for encouraging ethnic moderation.

We illustrate such a situation hypothetically for the case of Fiji, a country where, inspired by Horowitz's theories in 1997, the alternative vote was adopted for national parliamentary elections. In Fiji there are essentially only two major groups, native Fijians and non-native Fijians (predominantly of Indian descent, brought in by the British to work on the plantations). Thus, in Fiji, we can envision the existence of a unidimensional continuum anchored at one end by radical ethnic Fijian views, and by radical Indian views at the other end.

We argue that a necessary condition for AV to foster the "politics of ethnic moderation" is that the moderate position already has (at least potential) majority support. But, even if it does, and even if preferences are single-peaked along unidimensional continuum with ethnic radicalism of each type as the defining poles, we also show that outcomes under AV do not necessarily favor moderation. In particular, even with single-peaked preferences, non-moderate parties may, under certain circumstances emerge victorious.

\section{Formalizing the Horowitz model and examining its implications}

\subsection{The key elements of the Horowitz model}

Horowitz views the alternative vote, despite its fundamentally majoritarian character, as less divisive for plural societies than simple plurality (a.k.a. first past the vote) voting. Horowitz sees the alternative vote as fostering interethnic accommodation and moderation through two different types of effects; one type affecting voters, the other affecting parties.

First, by being asked to generate a preferential ballot, voters of a given ethnic group may choose to express support for inter-ethnic accord by ranking moderate parties associated with the other ethnic group ahead of radical parties associated with their own ethnic group. ${ }^{10}$ While Horowitz assumes that, in an ethnically divided society, "voters will generally not cross ethnic lines" (Horowitz, 1991c: 179), he also posits that, with a preferential ballot, at second or third-preference, the voter might be willing to give support to moderate party from the another ethnic group. As he explains, "the purpose of incentives is to create floating voters at some level of preference" (Horowitz, 
1991c: 179). Thus, it could be the case that a radical party of a given ethnic group might be a plurality winner but still lose out to a moderate party of either its own or the other ethnic group as a result of eventual lower order ballot transfers.

Second, in Horowitz's view, under AV, political parties acquire a stake in bidding for second- or lower preferences outside their own ethnic group. To attract such support, parties might potentially adopt more conciliatory or moderate stances on ethnically divisive issues. "Electorally, the way to induce politicians to be moderate is to structure voting arrangements so politicians must rely, in part, on votes delivered by members of a group other than their own. Such incentives are effective because those votes will not be forthcoming unless the candidates receiving them can be portrayed as being moderate on inter-ethnic issues" (1993: 24). Since the moderate parties are viewed as more likely to be able to obtain such cross-ethnic support than extremist parties, in Horowitz's view, AV will 'make moderation rewarding and penalize extremism' (Horowitz, 1991b: 452).

Third, and relatedly, moderate parties who make appeals to voters across the ethnic divide also acquire an incentive to enter into deals with other parties over the exchange of preferences, opening up not just the potential for policy adjustments on formerly divisive issues, but also creating direct incentives for cross-ethnic electoral alliances. "The price of successful negotiation is intergroup accommodation and compromise. The exchange of second or third preferences, based on reciprocal concessions on ethnic issues, is likely to lead to an accommodative interethnic coalition if no party can form a government alone (see Horowitz, 1991c: 189). These coalitions, anticipates Horowitz, are likely to be more robust 'coalitions of commitment' than the 'coalitions for convenience' often established by parties after an election under PR systems) (see Horowitz, 1985: 365-388; 1991c: 177, 182; 1993: 26).

In these three ways, Horowitz anticipates that, under AV, the 'rules of the game will generally favor accommodation', 'repel conflict-prone claims' and 'encourage pro-system parties'. ${ }^{11}$

\subsection{Formalizing the Horowitz model}

The Horowitz model can be reformulated in terms of standard social choice theory if voters (or candidates or parties given voter proxies) generally rank alternatives so as to yield "single-peaked" curves (Arrow, 1951: 75-76; Black, 1958). ${ }^{12}$ For example, in post-war Europe, the left-right division was such that those on the right were likely to rank centrists higher than leftists, and vice versa. Wherever their own position on the spectrum, for at least the major political parties, virtually all knowledgeable individuals saw the party array on the left-right dimension in the same fashion. In other circumstances, 
however, perceptions of party locations may be in dispute or there may be more than one dimension which shapes political divisions, with the consequence that no single-peaked ranking of preferences can be found. Russia's infamous alliances between hard-line Nationalists and former Communists, for example, defied the familiar Cold-War left-right axis.

In a bipolar society marked by deep ethnic divisions, we might expect that the political continuum would be defined around ethnic divisions rather than ideology; with radical elements of one group occupying one pole, and radicals from the other group at the other pole. The Horowitz model assumes predominantly ethnic-based loyalties of this type. In Fiji, where since independence elections have largely been fought as a contest between ethnically defined 'Indian' (I) and 'Fijian' (F) parties, we can construct a streamlined model on the assumption that there are only four parties; one radical (r) and one moderate $(\mathrm{m})$ party for each of the two groups. We shall denote these as $\mathrm{rI}, \mathrm{mI}, \mathrm{mF}$ and $\mathrm{rF}$, respectively.

Plotting this ethnic continuum along the $\mathrm{x}$-axis, we can generate a set of curves that denote the eight possible single-peaked rankings of the four parties (shown in Figures 1a and 1b). The lines are 'single-peaked' in the sense that they change their shape at most once, and where they do change their shape it is from an upward to a downward slope. ${ }^{13}$ The eight utility functions in the graph of Figure 1 are each single-peaked with respect to the continuum (rI, mI, mF, rF). In that figure, voter utility is shown on the y-axis, and the four alternatives $(\mathrm{rI}, \mathrm{mI}, \mathrm{mF}, \mathrm{rF})$ are shown on the $\mathrm{x}$-axis in the posited order.

In total, there are 24 possible rankings of these four hypothetical parties. Only 8 of these are single-peaked with respect to the posited ethnic continuum. The other 16 are non-single-peaked. ${ }^{14}$ Non-single-peaked rankings along the ethnically-defined continuum set out along the $\mathrm{x}$-axis in Figure 1 would have multiple peaks or a central trough, and may be deemed indicative of the presence of alternative dimensions to the political process. To envision a non-single-peaked preference ordering with respect to that continuum, just consider a voter who prefers $\mathrm{rF}$ to $\mathrm{rI}$ to $\mathrm{mF}$ to $\mathrm{mI}$. Were we to plot utility for that voter in the same figure, we would get a curve, which goes down (since $\mathrm{rF}$, on the far left, is preferred to rI) and then up (since rI, on the far right, is preferred to both $\mathrm{mF}$ and $\mathrm{mI}$ ). This non-singled-peaked curve violates our requirement that, if there is a change of direction, it be up to down, not down to up.

In Table 1, we list the set of single-peaked voter preferences in terms of the preference rankings they give rise to. ${ }^{15}$

Assuming 'pure' ethnic voting, in the sense that voter first and second preferences are for the moderate and radical parties from their own ethnic 
(a) "Pure" Ethnic Single-Peaked Preference Curves

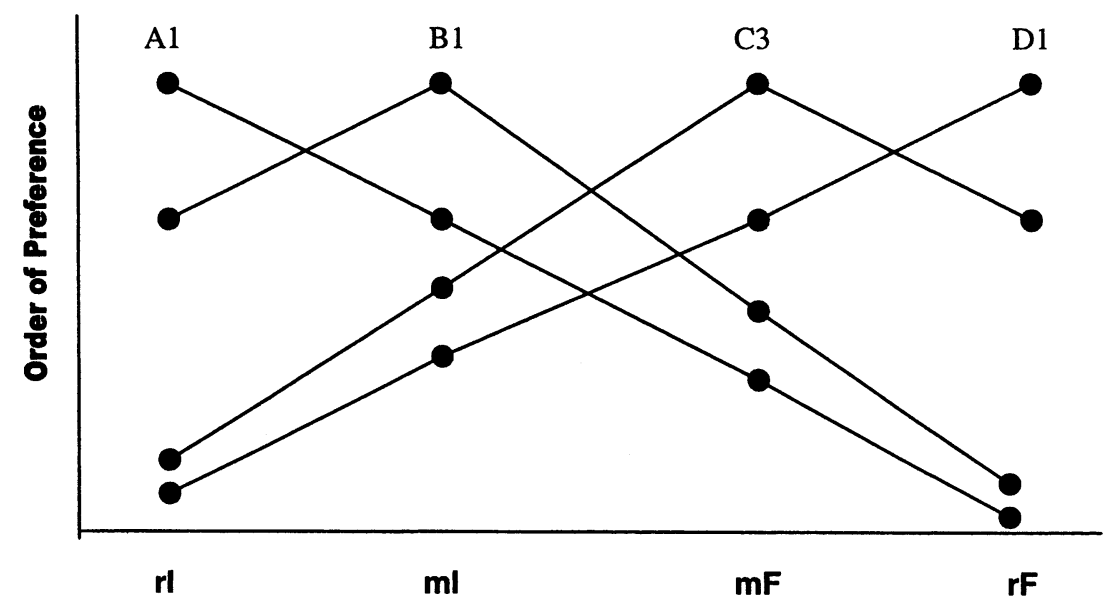

(b) Mild Ethnic Single-Peaked Preference Curves

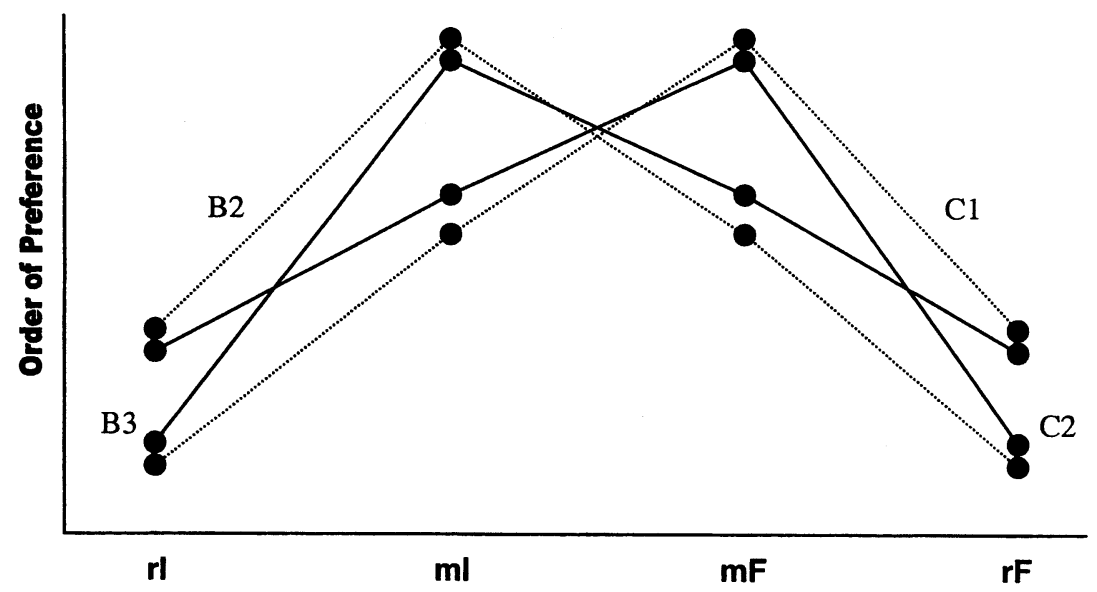

Figure 1. 
Table 1. Single-peaked preferences among four parties along a continuum anchored by a radical native Fijian party at one end and a radical Indo-Fijian party at the other end

\begin{tabular}{llllllll}
\hline Type A1 & Type B1 & Type B2 & Type B3 & Type C1 & Type C2 & Type C3 & Type D1 \\
\hline $\mathrm{rI}$ & $\mathrm{mI}$ & $\mathrm{mI}$ & $\mathrm{mI}$ & $\mathrm{mF}$ & $\mathrm{mF}$ & $\mathrm{mF}$ & $\mathrm{rF}$ \\
$\mathrm{mI}$ & $\mathrm{rI}$ & $\mathrm{mF}$ & $\mathrm{mF}$ & $\mathrm{mI}$ & $\mathrm{mI}$ & $\mathrm{rF}$ & $\mathrm{mF}$ \\
$\mathrm{mF}$ & $\mathrm{mF}$ & $\mathrm{ri}$ & $\mathrm{rF}$ & $\mathrm{rF}$ & $\mathrm{rI}$ & $\mathrm{mI}$ & $\mathrm{mI}$ \\
$\mathrm{rF}$ & $\mathrm{rF}$ & $\mathrm{rF}$ & $\mathrm{rI}$ & $\mathrm{rI}$ & $\mathrm{rF}$ & $\mathrm{rI}$ & $\mathrm{rI}$ \\
\hline
\end{tabular}

group, ${ }^{16}$ one might expect the array of likely rankings to assume the shape of the subset of four single-peaked curves shown in Figure 1a. If there is a greater willingness to transfer second preference allegiances across the ethnic divide (or greater hostility to extremists), we might witness the occurrence of an array of preferences closer to the other four single-peaked preference curves shown in Figure 1b. These preference curves all rank both moderate parties (mI, mF) above the radical parties of the two ethnic groups (rI, rF).

\subsection{Implications of the Horowitz model for moderate outcomes}

When preferences are single-peaked, and therefore necessarily transitive, there exist several voting systems that will tend to favor options (or candidates) found towards the center of the spectrum. Borda's proposed method of assigning weighted scores ${ }^{17}$ to each consecutive preference, and various methods (called Condorcet extension methods) ${ }^{18}$ that require us to consider the results of pairwise voting among the entire set of candidates, 'tend to eliminate candidates who are viewed as extremists of one kind or another. ${ }^{19}$ Indeed when preferences are single-peaked, the latter methods guarantee victory for the alternative favored by the 'median' voter. For preferences which can arrayed along a line, the median voter, made famous by Downs (1957), is (for an odd number of voters) simply the voter who has half of the voters having their most preferred alternative to his left, and half of the voters having their most preferred alternatives to his right.

How effective is the Australian-style AV system at delivering the result most preferred by the median voter?

1. For all 8 types of single-peaked preference curves, the moderate candidate of the other ethnic group invariably obtains a higher preference than the radical candidate of that other ethnic group. Hence, one or other of the radical candidates always figures as last preference.

2. If preferences are single-peaked, supporters of moderate parties exhibit preference schedules which move downwards in two directions, leftwards or 
rightwards, whereas voters who place radical candidates in first position have nowhere else to go other than to move towards the center of the political spectrum.

These two features of single-peaked preference curves may appear to reinforce the proposition that the alternative vote fosters moderation.

3. Indeed, with single-peaked preferences, if all four types of party $(\mathrm{mF}$, $\mathrm{mI}, \mathrm{mI}, \mathrm{rI}$ ) contest a constituency, and no party has a majority of first place preferences, the median party must be one of the moderate parties. It must be the moderate party of whichever ethnic group constitutes a majority of the electorate. In such circumstances, the AV voting regime may yield an outcome favoring a moderate, or median, party.

Case 1 shows a 60\% majority ethnic Fijian constituency, in which successive stages of the AV count eliminate the extremist parties, and facilitate their votes being transferred towards the center.

The ultimate victor, the moderate Fijian party is also the median party and crosses the 50\% threshold at the third and final count. Note, however, that this example requires us to assume majority first preference support for the politics of ethnic moderation among both Fijians (40/20) and Indo-Fijians (30/10).

With modified assumptions, however, it is straightforward to show that AV's vote transfers may yield a very different outcome. Even when the median party is one of the moderate parties, the alternative vote does not guarantee it victory ${ }^{20}$ Assume a constituency similar to that shown in case 1 , although now with only $50 \%$ of voters backing moderate parties.

In this case, the first party eliminated is rI, and its second preference votes are transferred to $\mathrm{mI}$. The second party eliminated is $\mathrm{mF}$, and its second preference votes are transferred to $\mathrm{rF}$. Hence, $\mathrm{rF}$ emerges as the victor with $60 \%$ of the vote, despite $\mathrm{mF}$ being the median party and despite $50 \%$ of voters positioning moderate parties as their first preference. Note also that type B1 lower-order preferences do not come into play at the final count, ${ }^{21}$ and the fact that $\mathrm{rF}$ is lowest on the Indo-Fijian schedules of preferences makes no difference to the final result.

Consider the following scenario: in some given constituency no single party commands majority support, but most of the electorate is native Fijian. Thus, native Fijian support is divided between the moderate and the radical Fijian party. If, say, all Fijian voters have either Type C3 or Type D1 preferences, and more have Type D1 preferences than Type $\mathrm{C} 3$ preferences, in the above scenario, it is easy to see that the radical Fijian party, despite being extreme, is likely to be the winner under the alternative vote despite the fact that the moderate Fijian party is the median party. Under the above assumptions, if the moderate Fijian party is eliminated at some round of the alternative vote 


\section{$\underline{\text { Preferences }}$}

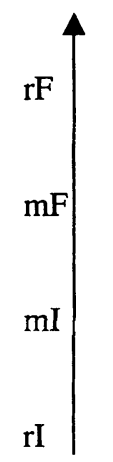

20

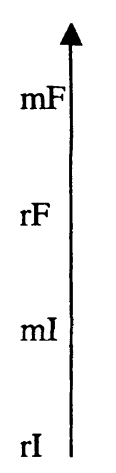

40 $\begin{aligned} & \mathrm{mI} \\ & \mathrm{mF} \\ & \mathrm{rF}\end{aligned} \mid$

30 $\begin{aligned} & \mathrm{rI} \\ & \mathrm{mF} \\ & \mathrm{rF}\end{aligned} \mid$

10

Fijian voters $(60)$

Indo-Fijian voters (40)

The Count

\begin{tabular}{lllll} 
& $\mathrm{rF}$ & $\mathrm{mF}$ & $\mathrm{mI}$ & $\mathrm{rI}$ \\
\hline First Count & 20 & 40 & 30 & 10 \\
Second count & 20 & 40 & 40 & excl \\
Third Count & excl & 60 & 40 & \\
\hline
\end{tabular}

Case 1.

transfer process while the radical Fijian party remains viable (which it would appear is likely to happen, since we are positing that the radical Fijian party has more first place support than the moderate Fijian party), then the radical Fijian party will receive the transfer votes of supporters of the moderate Fijian party and thus be elected. ${ }^{22}$

Is it possible to get results favouring moderation, or the outcome favoured by the median voter, even if a majority of voters give their first preference to extremist parties of their own group? Yes, but only if we make some rather severe distributional assumptions. Case 3 illustrates situation where a majority of Fijians (35/60) support $\mathrm{rF}$, while a majority of Indo-Fijians support rI (22/40). Here, the minority group parties (rI, mI) are eliminated 


\section{$\underline{\text { Preferences }}$}

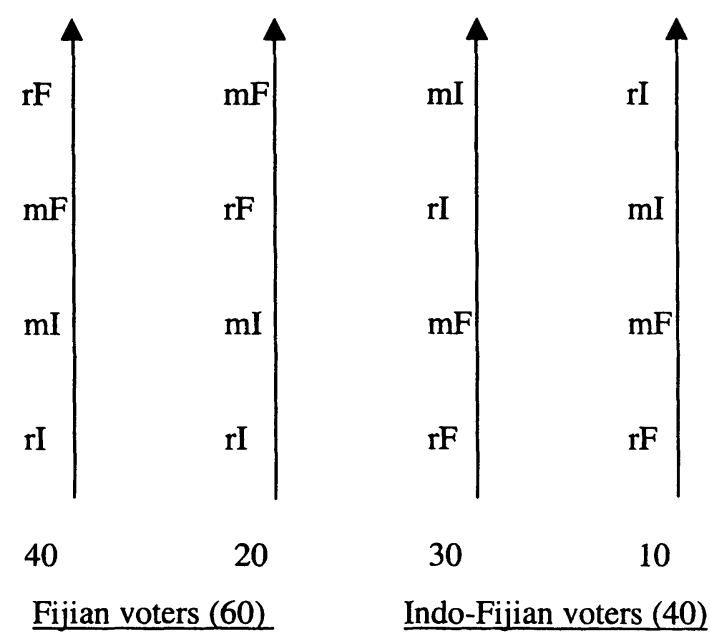

\section{The Count}

\begin{tabular}{lllll} 
& $\mathrm{rF}$ & $\mathrm{mF}$ & $\mathrm{mI}$ & $\mathrm{rI}$ \\
\hline First Count & 40 & 20 & 30 & 10 \\
Second count & 40 & 20 & 40 & excl \\
Third Count & 60 & excl & 40 & \\
\hline
\end{tabular}

Case 2.

and $\mathrm{rI}$ preferences are transferred over to the moderate party of the other ethnic group. That median party, $\mathrm{mF}$, wins, drawing on the lower-order preferences of Indian parties. Two crucial conditions here are (i) that $\mathrm{mF}$ (the median party) avoids getting eliminated at the first or second count and (ii) that all Indo-Fijian preference curves are single-peaked, implying that $\mathrm{rF}$ is placed in last or penultimate position. If only one voter who places $\mathrm{mI}$ as first preference were to switch their second preference from $\mathrm{mF}$ to $\mathrm{rI}$, it would be $\mathrm{mF}$ that would be eliminated at the third count and the result would change, with the median party failing to get elected.

Is it possible to obtain results favoring the extremist parties, even where there is majority support for the more moderate alternatives? No. In a four party situation with single-peaked preferences and majority first preference support in both communities for moderate parties, the median party cannot 


\section{$\underline{\text { Preferences }}$}

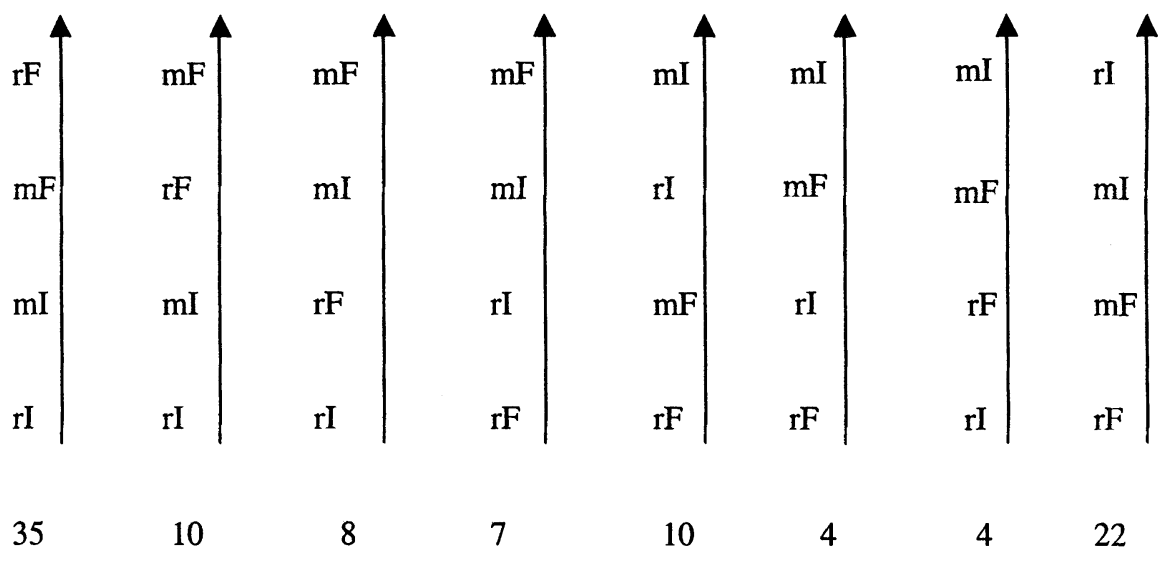

Fijian Voters (60)

$\underline{\text { Indian Voters (40) }}$

\section{The Count}

$\mathrm{rF} \quad \mathrm{mF} \quad \mathrm{mI} \quad \mathrm{rI}$

\begin{tabular}{lllll}
\hline First Count & 35 & 25 & 18 & 22 \\
Second count & 35 & 33 & excl & 32 \\
Third Count & 35 & 65 & - & excl \\
\hline
\end{tabular}

Case 3.

be eliminated. (proof available upon request from the authors). ${ }^{23}$ In this situation, the moderate parties must avoid elimination at the first count. One or other of the radical parties gets eliminated and these votes shift towards the center of the spectrum. It is necessary to assume an anti-moderation majority in one or other community, or in both communities, in order to get results, under these assumptions, that favor extremist parties.

Hence, the restrictive assumptions under which AV can be expected to yield a mild pro-moderation incentive are (a) single-peaked preferences, (b) presence of only four parties, (c) majority support for ethnic moderation within each entity or (d) a distribution of first or transferred preference votes 
not being such as to leave a potential moderate victor in last position at any stage during the count. Even under these assumptions, relatively erratic outcomes can occur depending upon which party ends up in third position at the penultimate count. ${ }^{24}$ Conversely, if there are more than four parties, which type of party eliminated at each stage of the count becomes much more uncertain. And, if there exist some non-single-peaked preferences, the overall bias of the electoral system becomes highly indeterminate. Preference votes need no longer necessarily flow along the continuum to consecutive positions along the ethnic $(\mathrm{x})$ axis, but may skip across intervening options or express accords between extremes against moderates.

\subsection{Implications of the Horowitz model for coalition structure}

Just as the Horowitz model has implications for the structure of voter preference orderings, it has closely related implications about the coalitional options of the parties. The Horowitz model can be taken to imply that party coalitions should be ideologically connected in the sense of Axelrod. ${ }^{25}$ This means that the only possible non-singleton and non-grand coalitions $\mathrm{s}^{26}$ should be $\mathrm{rI}+\mathrm{mI}, \mathrm{rI}+\mathrm{mI}+\mathrm{mF}, \mathrm{mI}+\mathrm{mF}, \mathrm{mI}+\mathrm{mF}+\mathrm{rF}$, and $\mathrm{mF}+\mathrm{rF}$. Coalitions such as ones between $\mathrm{rI}$ and $\mathrm{mF}$, but without $\mathrm{mI}$, or between $\mathrm{rI}$ and $\mathrm{rF}$ without both "intervening" moderate parties (i.e., other than the grand coalition), are excluded. $^{27}$

\subsection{An alternative model of party alliances}

We now wish to consider the implications of a different model of party coalitions than that suggested by Horowitz. We posit that there are circumstances where a party of one ethnic group may have more interest in coalescing with a party of the opposite ethnic group than with a party of its own ethnic group because parties of the same ethnic group are direct rivals for voters from that ethnic group and because the supporters of a given ethnic party may have more of a wish to see themselves rewarded by payoffs from the state than be concerned about rewards for members of their own ethnic group who are not party supporters.

These assumptions can generate pre-election party alliances that cut across ethnic lines (as in the Horowitz model), but ones that are motivated by quite different reasons than those posited by Horowitz. Moreover, the above assumptions can generate kinds of alliances that are verboten by the Horowitz model, such as $\mathrm{rI}+\mathrm{mF}$ or $\mathrm{mI}+\mathrm{rF}$ (or, potentially, even $\mathrm{rI}+\mathrm{rF}$ ), in addition to alliances involving $\mathrm{rI}+\mathrm{mI}, \mathrm{mI}+\mathrm{mF}$, or $\mathrm{mF}+\mathrm{rF}$.

For illustrative purposes, we show in Table 2 vote ranking patterns consistent with a non-ideologically connected partisan alliance between $\mathrm{rI}+\mathrm{mF}$, 
Table 2. Hypothetical preferences among four parties advocated for "above the line" voting: Based on non-ethnic connected partisan alliance patterns pitting $\mathrm{rI}+\mathrm{mF}$ against $\mathrm{mI}+\mathrm{rF}$

\begin{tabular}{|c|c|c|c|c|c|c|c|}
\hline $\begin{array}{l}\text { Type A2 } \\
\text { (Indo- } \\
\text { Fijian } \\
\text { district) }\end{array}$ & $\begin{array}{l}\text { Type A3 } \\
\text { (Fijian } \\
\text { district) }\end{array}$ & $\begin{array}{l}\text { Type B4 } \\
\text { (Indo- } \\
\text { Fijian } \\
\text { district) }\end{array}$ & $\begin{array}{l}\text { Type B5 } \\
\text { (Fijian } \\
\text { district) }\end{array}$ & $\begin{array}{l}\text { Type C4 } \\
\text { (Indo- } \\
\text { Fijian } \\
\text { district) }\end{array}$ & $\begin{array}{l}\text { Type C5 } \\
\text { (Fijian } \\
\text { district) }\end{array}$ & $\begin{array}{l}\text { Type D2 } \\
\text { (Indo- } \\
\text { Fijian } \\
\text { district) }\end{array}$ & $\begin{array}{l}\text { Type D3 } \\
\text { (Fijian } \\
\text { district) }\end{array}$ \\
\hline rI & rI & $\mathrm{mI}$ & $\mathrm{mI}$ & $\mathrm{mF}$ & $\mathrm{mF}$ & $\mathrm{rF}$ & $\mathrm{rF}$ \\
\hline $\mathrm{mF}$ & $\mathrm{mF}$ & $\mathrm{rF}$ & $\mathrm{rF}$ & $\mathrm{rI}$ & rI & $\mathrm{mI}$ & $\mathrm{mI}$ \\
\hline $\mathrm{rF}$ & $\mathrm{mI}$ & $\mathrm{mF}$ & $\mathrm{rI}$ & $\mathrm{rF}$ & MI & $\mathrm{mF}$ & rI \\
\hline $\mathrm{mI}$ & $\mathrm{rF}$ & $\mathrm{rI}$ & $\mathrm{mF}$ & $\mathrm{mI}$ & $\mathrm{rF}$ & rI & $\mathrm{mF}$ \\
\hline
\end{tabular}

on the one hand, and $\mathrm{mI}+\mathrm{rF}$, on the other - in which supporters of each party are assumed to rank the alliance partner of a party immediately below the party itself. ${ }^{28}$ Looking at Table 2 we see no overlap with the single-peaked ballot options laid out in Table 1.

Now we wish to consider the patterns of likely above the line rankings that would be proposed by a different type of alliance, an alliance between an $\mathrm{mI}$ and a $\mathrm{mF}$ party versus an alliance of convenience between an $\mathrm{rI}$ and a $\mathrm{rF}$ party. Clearly, if we begin with an $\mathrm{mI}+\mathrm{mF}$ alliance, there are incentives for strange bedfellows to partner, since if the rI party and the $\mathrm{rF}$ party each contest solo, under the alternative vote they are likely to be eliminated because, absent an alliance between them, once votes are transferred from the $\mathrm{mI}$ to the $\mathrm{mF}$ party, or vice versa, it is likely that the pattern of vote transfers from whichever one of the radical parties is first to be eliminated will benefit the remaining center party far more than it would benefit the remaining radical party. Only if the extremes coalesce into a working alliance, can they expect that their transfers will go to each other rather than going to a candidate of the centrist alliance. In short, the logic of the alternative vote when there is a centrist coalition in place is that a second dimension of conflict in addition to the ethnic one, one defined in terms of "ins" versus "outs," with an incentive to gang up on a governing coalition that is perceived as likely to win, might even lead to a alliance between the most unlikely of bedfellows.

In Fiji, parties possessed considerable ability to affect the voter choices of party supporters in each constituency so as to use the AV system to favor whatever alliances across parties the party leaders supported. That is because, in Fiji, the burden need not be on the voters, themselves, to perfectly carry out the instructions of party leaders as to how to rank order the candidates of the different parties once they were in the ballot booth. In Fiji what are 
Table 3. Hypothetical preferences among four parties advocated for "above the line" voting: Based on one non-ethnically connected partisan alliance patterns and one ethnically connected partisan alliance pitting $\mathrm{rI}+\mathrm{rF}$ against $\mathrm{mI}+\mathrm{mF}$

\begin{tabular}{|c|c|c|c|c|c|c|c|}
\hline $\begin{array}{l}\text { Type A4 } \\
\text { (Indo- } \\
\text { Fijian } \\
\text { district) }\end{array}$ & $\begin{array}{l}\text { Type A4 } \\
\text { (Fijian } \\
\text { district) }\end{array}$ & $\begin{array}{l}\text { Type B2 } \\
\text { (Indo- } \\
\text { Fijian } \\
\text { district) }\end{array}$ & $\begin{array}{l}\text { Type B3 } \\
\text { (Fijian } \\
\text { district) }\end{array}$ & $\begin{array}{l}\text { Type C1 } \\
\text { (Indo- } \\
\text { Fijian } \\
\text { district) }\end{array}$ & $\begin{array}{l}\text { Type C2 } \\
\text { (Fijian } \\
\text { district) }\end{array}$ & $\begin{array}{l}\text { Type D4 } \\
\text { (Indo- } \\
\text { Fijian } \\
\text { district) }\end{array}$ & $\begin{array}{l}\text { Type D5 } \\
\text { (Fijian } \\
\text { district) }\end{array}$ \\
\hline rI & ri & $\mathrm{mI}$ & $\mathrm{mI}$ & $\mathrm{mF}$ & $\mathrm{mF}$ & $\mathrm{rF}$ & $\mathrm{rF}$ \\
\hline $\mathrm{rF}$ & $\mathrm{rF}$ & $\mathrm{mF}$ & $\mathrm{mF}$ & $\mathrm{mI}$ & $\mathrm{mI}$ & rI & rI \\
\hline $\mathrm{mF}$ & $\mathrm{mI}$ & $\mathrm{rF}$ & $\mathrm{rI}$ & $\mathrm{rF}$ & rI & $\mathrm{mF}$ & $\mathrm{mI}$ \\
\hline $\mathrm{mI}$ & $\mathrm{mF}$ & $\mathrm{rI}$ & $\mathrm{rF}$ & $\mathrm{rI}$ & $\mathrm{rF}$ & $\mathrm{mI}$ & $\mathrm{mF}$ \\
\hline
\end{tabular}

called above the line votes have been permitted. ${ }^{29}$ This means that a voter could designate a single candidate to whom the voter would cede his vote. The rank ordering of candidates filed in advance with election officials by the designated candidate would then determine how that voter's ballot would be tallied. Since parties in Fiji could affect what slates were proposed by each of the party's candidates, the political parties could determine the preference ranking for those voters who had ceded their ranking privilege to a party candidate. Moreover, this turned out to be almost all the voters!

For illustrative purposes, we show in Table 3 expected "above the line" rankings derived from a contest between a "connected" partisan alliance between $\mathrm{mI}$ and $\mathrm{mF}$ versus a "non-connected" alliance of $\mathrm{rI}$ plus $\mathrm{rF}$. As noted previously, while the two parties in each alliance might each propose rankings with their own party at the top and the other alliance party second, it might also be the case that in constituencies where the other party could be expected (based on ethnic composition of the constituency) to be stronger, parties in an alliance might defer to one another, i.e., list the other party first. ${ }^{30}$ When we generate the preference rankings such alliances should be expected to propose for their above the line supporters, we find that the proposed above the line rankings of the parties in the "connected" alliance can be expected to be single-peaked rankings with respect to our previously defined "ethnic" dimension; but the above the line rankings of the parties in the nonconnected alliance (the alliance involving the radical parties of the two ethnies) would be expected not to be single-peaked.

Allowing for party-alliance-based preferences of the sort shown in Table 2 or Table 3 changes our intuitions about how likely moderate parties are to be successful under the alternative vote. Moreover, when we allow the kinds of 
non-single-peaked preference rankings shown in Table 2 or Table 3, we can get some rather "funny" outcomes under the alternative vote.

In the illustration of above the line voting rankings shown in Table 2, we have posited cross-ethnic alliances involving the moderate party of one ethnic group and the radical party of the other ethnic group. We might think that this would enhance the likelihood of moderate parties winning office. For example, if pre-election alliance patterns are as posited in Table 2, if $\mathrm{mF}$ has more first place support than $\mathrm{rF}$, and $\mathrm{rI}$ (its coalition partner) has more first place support than $\mathrm{mI}$, we might think that both $\mathrm{mF}$ and $\mathrm{rI}$ would do well. But, consider a constituency with a Fijian majority in which $\mathrm{mF}$ is the median party when voting is along an ethnic continuum.

In this constituency, if $\mathrm{rI}$ has more first place support than $\mathrm{mF}$, which is possible even though the district has a Fijian majority, you can get situations in which only rI wins any seats! How? Well, under the above assumptions, $\mathrm{mF}$ is likely to be eliminated before $\mathrm{rI}$. When $\mathrm{mF}$ is eliminated, its support goes to rI; which, under the above assumptions, assures the victory of the radical Indo-Fijian party. Thus, under the alternative vote, not only can median parties lose when voting is ethnically-oriented, but, also, when preferences are generated by above the line alliance among nonconnected parties, even median parties who are attracting preference transfer support from a coalition partner can be denied representation.

When there are independents and fringe parties in the contest as well, and when some voters do not provide a full preference ordering, or vote tactically, some even more bizarre results can obtain under the alternative vote when votes are determined by party alliances and vote preference rankings are not all single-peaked. For example, if supporters of each major coalition place the candidates of the parties in the other major coalition at the bottom of their preference orderings, then "no-hope" independent candidates, who are thus put in the middle of most voter's preference orderings simply to avoid giving a high rank to the "serious" opposition, may actually win.

\section{Discussion}

Because the actual election array in Fiji involved more than four parties, the simplified models of possible scenarios for party competition presented above are best used as heuristics. Yet, some of the key intuitions we derive from these models, e.g., the potential for non-single-peaked preferences and a concomitant heightened potential for losses by moderate parties under AV, are very useful in understanding what happened in the Fijian election of 1999. Elsewhere we have argued that what we saw in Fiji in 1999 could best be described as an $\mathrm{mI}$ and a $\mathrm{mF}$ party alliance ${ }^{31}$ (the "in parties") versus an alliance 
of convenience (of "out parties") between an rI and two different $\mathrm{mF}$ parties, ${ }^{32}$ with two $\mathrm{rF}$ parties basically running on their own. Thus, even though parties could relatively readily be placed on an ethnic continuum, the 1999 election in Fiji was not fought solely (or even primarily) with respect to that continuum in the way that Horowitz had in mind. Moreover, that election did not have the consequences of favoring moderation that Horowitz might have hoped for. Voter choices and party alliance patterns under the alternative vote in Fiji in 1999 generated outcomes very far from the preferences of Horowitz's (hypothetical) median ethnically moderate voter. These electoral results were widely seen as unfair and unrepresentative. The 1999 outcome exacerbated inter-ethnic tensions, and helped to trigger a partly successful putsch in 2000 aimed at institutionalizing Fijian dominance over the government and abrogating the country's new constitution. ${ }^{33}$

\section{Notes}

1. We use the term "ethnic group" or "ethny" to designate groups that are viewed both by themselves and by non group-members as having a defined identity that allows members of the group to be clearly distinguishable from other citizens in terms of genotype, or phenotype, or language, or religion, or other cultural markers. This terminology is common in the sociological literature on ethnicity (personal communication, Robin Williams, February 2000).

2. Nations which are multi-ethnic in character but in which ethnic differences have been minimized in importance are commonly referred to as pluralistic. In contrast, plural, or "deeply divided," societies are those where politics is organized largely or entirely along ethnic lines, and two or more ethnic groups compete for power at the center of the political system. The potential for severe ethnic conflict is greatest in plural societies. Another name for plural society is (deeply) divided society.

3. For recent reviews see e.g., Montville, 1991; Sisk and Reynolds, 1998; Grofman and Stockwell, 2002; Williams, 1994.

4. The extreme pole of this approach involves advocacy of political breakup into states that are more ethnically homogeneous.

5. See especially Grofman and Stockwell (2002), who draw on ideas about tradeoffs in Buchanan and Tullock (1962).

6. The alternative vote is the single-district variant of the multi-seat preferential voting method, the single-transferable vote (STV). In STV and AV voters are asked to rank order (all) the candidates, but only one of their preferences is actually tallied. First, talliers look at each voter's first place preferences. If no candidate receives sufficient votes to win based on these first place preferences then the (still feasible) candidate with the least first place support is dropped. If a voter has his vote tallied for a candidate who got eliminated through insufficient overall support, then the voter's preference is changed to the next still viable candidate on that voter's preference list. The process continues until all slots are filled. In AV, where only a single seat is to be filled, to win, a candidate must receive a majority of the votes (including transfers). In STV, where there are $m$ seats to be filled $(m>1)$, every candidate who receives more than a $1 /(m+1)$ share of the vote 
(including transfers) is elected. However, in STV, if a candidate is elected with more than the exact share (quota) of votes needed to win, then the "excess" votes are (proportionally) transferred to the (still feasible) candidate ranked immediately below the chosen candidate on each list on which that candidate was at the top.

7. Horowitz's writings focus on the alternative vote, but he also has acknowledged the potential value of adopting STV as a mechanism for mitigating ethnic conflict, as had been done in Northern Ireland (see e.g., O'Leary, Lyne, Marshall and Rowthorn, 1993).

8. For example, an important Indo-Fijian parliamentarian, Jai Ram Reddy, asserted in 1992:

Mr. Speaker: Sir, you can have multiracialism in two ways. You can ... have multiracial parties ... That kind of multiracialism is, maybe, a bit premature for Fiji, perhaps we are not ready for it ... The communal pools [sic - pulls?] are extremely strong ....we are locked into a situation where we will continue to look into the indefinite future in terms of race ... There is another kind of multiracialism ... Let us each be in our separate racial compartment ... Let communal solidarity prevail ... Let everyone be united, but from our respective positions of unity, let us accept that we must co-exist and work together ... It may be ... that that is a more realistic approach.' (Fijian House of Representatives, 1992. Parliamentary Debates. Hansard: 730-731. 1992).

9. Definitions of "median voter" and of "single-peakedness" will be given in the next section.

10. In an AV contest, "Even if voters are not prepared easily to contemplate crossing ethnic lines, that is not an insurmountable problem, because second or third preferences could be made compulsory for a valid ballot" (Horowitz, 1991c: 190). Indeed, in Fiji, ballots with "too few" recorded preferences are treated as invalid. Voters were required to rank order $75 \%$ of candidates. (This compulsory aspect does not hold for all countries using AV. For discussion of the rules in other countries using AV or STV see various essays in Bowler and Grofman, 2000). On the other hand, the element of compulsion may force a kind of arbitrariness to recorded lower-order preferences. Such lower-order preferences were actually decisive in some instances in the Fijian election of 1999.

11. Horowitz, 1991c: 198, 183, 203; see also Sisk, 1996: 10; Reilly, 1997: 2.

12. Single-peakedness is also known among social choice theorists as Sen's NW condition (Sen and Pattanaik, 1969; Sen, 1970).

13. Single-peaked curves are ones, which are either always upward sloping, or always downward sloping, or always horizontal, or which are upward sloping to a particular point and down ward sloping beyond that point (i.e. $\cap$-shaped). On this definition a single-peaked curve is one which changes its direction at most once, from up to down (Black, 1958: 7). The lines shown in Figure 1, however, are purely heuristic, representing the rough shape of the individual voter's utility function. In particular, we have arbitrarily shown the curves as consisting of straight-line segments.

14. There are $24(4 !=4$ factorial $=4 \times 3 \times 2 \times 1))$ different possible (strong) voter preference orderings involving the four parties, but, for a fixed continuum, only 8 of these preference orderings $\left(2^{3}\right)$ are permitted by single-peakedness.

15. Following the logic of Horowitz, we would posit that only single-peaked preferences should exist. For example, we would posit that radical members of a given group will first prefer radical parties associated with that same group, then moderate parties of that same group, then moderate parties of the other group, and last and least, radical parties of the other group. This latter ordering gives rise to what, in Table 1, we have labeled Type A1 preferences (when we are considering the preferences of Fijian extremists) and Type D1 preferences (when we are considering the preferences of Indo-Fijian extremists). 
16. What is often thought of as "pure ethnic voting" may be thought of as a subset of the Horowitz model of voting along an ethnically defined continuum. In pure ethnic voting, we may still think of voters as having single-peaked preferences along the continuum (rI, $\mathrm{mI}, \mathrm{mF}, \mathrm{rF}$ ), but now what we have identified in Table 1 as Types B2 and B3 and Types $\mathrm{C} 1$ and $\mathrm{C} 2$ voter preferences are ruled out. In other words, in pure ethnic voting, voters who are I's must put $\mathrm{mI}$ and $\mathrm{rI}$ at their top two their preferences, and always prefer $\mathrm{mF}$ to $\mathrm{rF}$; while voters who are F's must put $\mathrm{mF}$ or $\mathrm{rF}$ as their top two preferences, and always prefer $\mathrm{mI}$ to $\mathrm{rI}$.

17. See Black, 1958; Saari, 1995.

18. Condorcet's method of exhaustive pairwise contests (described in Black, 1958) was probably the first such method to be proposed (Young, 1977).

19. See Black, 1958; Arrow, 1951: 80.

20. Black (1958) recognised that, even with single-peaked preferences, STV would not necessarily result in victory for the 'majority' (i.e., median) candidate. His demonstration applies equally to the single-member version of STV, the AV system (see p. 72, p. 74). Black's warning that, with the double-ballot system, the 'majority candidate may be thrown out at the first round' also applies equally to AV.

21. The 'two party preferred' count is the well-established Australian expression for what we are calling the 'final count.'

22. Hence, Winston Churchill's observation about decisions under the alternative vote being determined by the 'hindmost' candidates preferences.

23. This proposition means that for four parties or for less than four party competition along a single dimension, the alternative vote is always at least as likely as plurality voting (FPP) to choose the alternative preferred by the median voter. Arend Lijphart (1991b) has claimed that the incentives for accommodation under AV are actually similar to those under FPP. Under AV majority parties are expected (by Horowitz) to secure preferences from smaller extremists, under FPP (according to Lijphart) the smaller parties step aside to avoid splitting the vote. Because we are not allowing for the possibility of strategic withdrawal, our results do not contradict this expectation; we are only making comparisons between AV and FPP for a fixed number of parties.

24. Relatively arbitrary effects depending on which party ends up in second and third position at the penultimate count, and thus gets eliminated, are a well-established hallmark of the alternative vote, and can, as with STV, lead to bizarre non-monotonic outcomes where an increase in support for a party ultimately causes its defeat (see Alexander, 1988: 53; Brams and Fishburn, 1984; Doron and Kronick, 1977).

25. See Axelrod, 1970. See also deSwaan, 1970, 1973; Grofman, 1982, 1996; Straffin and Grofman, 1984; Grofman, Straffin, and Noviello, 1996.

26. The grand coalition consists of all four parties.

27. Note also that, in "pure ethnic voting," as we have previously defined the term, only ethnically rooted party coalitions are feasible, i.e., $\mathrm{mI}+\mathrm{rI}$, or $\mathrm{mF}+\mathrm{rF}$. Such coalitions are a subset of the ideologically connected coalitions identified above.

28. Another possibility is that, in constituencies where the other party could be expected (based on ethnic composition of the constituency) to be stronger, parties in an alliance might defer to one another, i.e., list the other party first. As we show elsewhere this phenomenon of a party not listing its own candidate first was found in the 1999 election.

29. Also see discussion in the next section.

30. As we show in other work, such reversals of preferences actually took place in some constituencies in the 1999 Fijian election.

31. In 1999, these were the NFP $(\mathrm{mI})$ and the SVT $(\mathrm{mF})$. 
32. In 1999, these were the FLP ( $\mathrm{rI})$ and FAP $(\mathrm{mF})$ and PANU $(\mathrm{mF})$.

33. This is discussed in further detail in Fraenkel $(2000,2001)$.

\section{References}

Alexander, L. (1988). Note of reservation. In Report of the independent commission on the voting system, HMSO: 53.

Arrow, K.J. (1962). Social choice and individual values. (1st edition, (1951). New York: John Wiley and Sons.

Axelrod, R.M. (1970). Conflict of interest: A theory of divergent goals with applications to politics. Chicago: Markham Publishing Company.

Black, D. (1958). The theory of committee and elections. London and New York: Cambridge University Press (reprinted in 1992 by Kluwer Press).

Bowler, S. and Grofman, B. (Eds.) (2000). Elections in Australia, Ireland, an Malta under the single transferable vote: Reflections on an embedded institution. Ann Arbor: The University of Michigan Press.

Brams, S. and Fishburn, P. (1984). Some logical defects of the single transferable vote. In A. Lijphart and B. Grofman (Eds.), Choosing an electoral system: Issues and alternatives, 147-151. New York: Praeger.

Buchanan, J.M and Gordon Tullock. (1962). The calculus of consent: Logical foundations of constitutional democracy. Ann Arbor, MI: University of Michigan Press.

deSwaan, A. (1970). An empirical model of coalition formation as an N-person game of policy minimization. In G. Groennings, E.W. Kelley, and M. Leiserson (Eds.), The study of coalitional behavior, 424-444. New York: Holt, Rinehart.

deSwaan, A. (1973). Coalition theories and cabinet formation: A study of formal theories of coalition formation as applied to nine European parliaments after 1918. Amsterdam: Elsevier.

Diamond, L. and Plattner, M.F. (Eds.) (1994). Nationalism, ethnic conflict, and democracy. Baltimore: Johns Hopkins University Press.

$\rightarrow$ Doron, G. and Kronick, R. (1977). Single transferable vote: An example of a perverse social choice function. American Journal of Political Science 21: 303-312.

Downs, A. (1957). An economic theory of democracy. New York: Harper and Row.

Fraenkel, J. (2000). The clash of dynasties and the rise of demagogues, Fiji's Tauri Vakaukauwa of May 2000. Journal of Pacific History 35 (3).

Fraenkel, J. (2001). The alternative vote system in Fiji: Electoral engineering or ballotrigging? Journal of Commonwealth and Comparative Politics 39 (2): 1-31.

Grofman, B. (1982). Dynamic model of protocoalition formation in ideological $n$-space. Behavioral Science 27: 77-90.

Grofman, B. (1996). Extending a dynamic model of protocoalition formation. In N. Schofield (Ed.), Collective decision making: Choice and political economy, 265-280. Boston: Kluwer-Nijhoff.

Grofman, B. and Stockwell, R. (2002). Institutional design in plural societies: Mitigating ethnic conflict and fostering stable democracy. In R. Mudambi, P. Navarra and G. Sobbrio (Eds.), Economic welfare, international business and global institutional change. Cheltenham, UK: Elgar. 
Grofman, B., Straffin P. and Noviello, N. (1996). The sequential dynamics of cabinet formation, stochastic error, and a test of competing models. In N. Schofield (Ed.), Collective decision making: Choice and political economy, 281-293. Boston: Kluwer-Nijhoff.

Horowitz, D.L. (1985). Ethnic groups in conflict. Berkeley: University of California Press.

Horowitz, D.L. (1991a). Ethnic conflict management for policymakers. In J. Montville (Ed.), Conflict and peacemaking in multiethnic societies, 115-130. Lexington, MA: Lexington Books.

Horowitz, D.L. (1991b). Making moderation pay: The comparative politics of ethnic conflict management. In J. Montville (Ed.), Conflict and peacemaking in multiethnic societies, 451-476. Lexington, MA: Lexington Books.

Horowitz, D.L. (1991c). A democratic South Africa? Constitutional engineering in a divided society. Berkeley: University of California Press.

Horowitz, D.L. (1993). Democracy in divided societies. Journal of Democracy 4: 18-38.

Lijphart, A. (1977). Democracy in plural societies: A comparative exploration. New Haven: Yale University Press.

Lijphart, A. (1991a). The power sharing approach. In J. Montville (Ed.), Conflict and peacemaking in multiethnic societies, 490-510. Lexington, MA: Lexington Press.

Lijphart, A. (1991b). The alternative vote: A realistic alternative for South Africa? Politikon 18: 91-101.

$\rightarrow$ Lijphart, A. (1996). The puzzle of Indian democracy: A consociational interpretation. American Political Science Review 90: 258-268.

Lijphart, A. (1997). Disproportionality under alternative voting: The crucial - and puzzling case of the Australian senate elections, 1919-1946. Acta Politica 32: 924.

Montville, J. (Ed.). (1991). Conflict and peacemaking in multiethnic societies. Lexington, MA: Lexington Books.

O'Leary, B., Lyne, T., Marshall, J. and Rowthorn, B. (1993). Northern Ireland: Sharing authority. London: Institute for Public Policy Research.

Reilly, B. (1997). Preferential voting and political engineering: A comparative study. Journal of Commonwealth and Comparative Politics 35: 1-19.

Saari, D. (1995). The basic geometry of voting. Berlin: Springer-Verlag.

Sen, A.K. (1970). Collective choice and social welfare. San Francisco: Holden-Day, and Edinburgh.

Sen, A.K. and Pattanaik, P. (1969). Necessary and sufficient conditions for rational choice under majority decision. Journal of Economic Theory 1: 178-202.

Sisk, T. (1996). Power sharing and international mediation in ethnic conflict. Washington, D.C.: Institute of Peace.

Sisk, T.D. (1997). Power sharing in multiethnic societies. In B.V. Lal and T.R. Vakatora (Eds.), Fiji and the world: Research papers of the Fiji constitutional review commission Volume 2. Suva, Fiji: University of the South Pacific.

Sisk, T. and Reynolds, A. (Eds.) (1998). Elections and conflict management in Africa. Washington, DC: Institute of Peace.

$\rightarrow$ Straffin, P. and Grofman, B. (1984). Parliamentary coalitions: A tour of models. Mathematics Magazine 57: 259-274.

$\rightarrow$ Williams, R.M. (1994). The sociology of ethnic conflicts: Comparative international perspectives. Annual Review of Sociology 20: 49-79.

Young, P. (1977). Extending Condorcet's rule. Journal of Economic Theory 16: 335-353. 